\title{
Metafrontier analysis of commercial and smallholder \\ tomato production: A South African case
}

AUTHORS:

Jabulile Z. Gwebu ${ }^{1,2}$

Nicolette Matthews ${ }^{1}$

\section{AFFILIATIONS:}

'Department of Agricultural

Economics, University of the

Free State, Bloemfontein,

South Africa

${ }^{2}$ Agricultural Research Council,

Pretoria, South Africa

CORRESPONDENCE TO:

Nicolette Matthews

\section{EMAIL:}

MatthewsN@ufs.ac.za

\section{DATES:}

Received: 03 Aug. 2017

Revised: 03 Oct. 2017

Accepted: 23 Mar. 2018

Published: 30 July 2018

\section{KEYWORDS:}

technical efficiency; smallholder farm support; production management; agricultural support programmes; resource use efficiency

\section{HOW TO CITE:}

Gwebu JZ, Matthews N. Metafrontier analysis of commercial and smallholder tomato production: A South African case. S Afr J Sci. 2018;114(7/8), Art. \#2017-0258, 8 pages. http://dx.doi.org/10.17159/ sajs.2018/20170258

\section{ARTICLE INCLUDES: \\ $\times$ Supplementary material \\ $\times$ Data set}

\section{FUNDING:}

Agricultural Research Council (South Africa)
South African agriculture is a dualist agricultural system with well-developed commercial farmers and resource-poor smallholder farmers. In an effort to address the dualist nature of agriculture, the South African government has developed a strategic plan to assist smallholder farmers in entering commercial markets. The strategic plan aims to advance subsistence and smallholder farmers into commercial production through improved resource management for sustainable food security and smallholder livelihood. However, the productivity of smallholder farmers continues to be very low compared with that of commercial farmers. Our aim was to compare tomato productivity for commercial and smallholder tomato farmers in the Nkomazi area (Mpumalanga Province) using a metafrontier analysis. We used an output-oriented data envelopment analysis metafrontier approach and the Tobit model to investigate smallholder and commercial farmers' technical efficiencies and related factors which affect tomato production. Results indicate that smallholder farmers have high levels of technical efficiency compared to the group frontier $(0.74)$, but they are less technically efficient compared to the metafrontier (0.51). The group efficiencies of the smallholder farmers also showed a large variation ranging from $3 \%$ to $100 \%$, while commercial farmers have high levels of efficiency compared to both the group frontier $(0.89)$ and the metafrontier $(0.88)$. Results from the Tobit regression indicate that farmers' managerial decisions are an important determinant of their technical efficiency. We conclude that smallholder farmers first need to increase their level of technical efficiency relative to their peers before aiming to compete with commercial farmers.

\section{Significance:}

- Smallholder farmers should first improve their resource use efficiency compared to their fellow smallholder farmers before they consider comparing themselves against the commercial farmers.

\section{Introduction}

The structure of the agricultural sector in South Africa is dualistic in nature, with the sector comprising the welldeveloped commercial sector and the resource-poor smallholder farmers. ${ }^{1}$ Sandrey and Vink2 as cited by Tshuma ${ }^{3}$, argue that the commercial sector in South Africa consists of a few very big, successful and profit-oriented farmers who mostly use advanced production technology. The smallholder-farming sector is, however, dominant in rural areas of South Africa where about $70 \%$ of the poorest households are found. ${ }^{3}$ According to the National Department of Agriculture ${ }^{4}$, commercial agriculture follows a more capital-intensive growth path while substantial agricultural resources lie unused or underutilised in rural areas.

In 2001, a strategic plan for South African agriculture was established ${ }^{4}$ with the vision of a united and prosperous agricultural sector. The vision was designed to bridge the inherent dualism and to maximise the contribution of the agricultural sector for economic growth and development. Since then the Department of Agriculture, Forestry and Fisheries ${ }^{5}$ developed a strategic plan to assist smallholder farmers to enter commercial markets. The strategic plan aims to advance subsistence farmers into commercial production through improved resource management for sustainable food security and smallholder livelihood. However, the productivity of smallholder farmers continues to be very low compared with that of commercial farmers. ${ }^{6}$

Others ${ }^{7,8}$ have argued that smallholder farmers' productivity could be improved by improving the technological application of resources. They further argued that yield could be improved by increasing technical efficiency of production, without involving additional production resources and without adopting new technology.

Most studies estimate technical efficiency levels and identify the sources of inefficiency for smallholder farmers ${ }^{9-17}$ or commercial farmers ${ }^{18,19}$. Studies that compare smallholder and commercial farmers' technical efficiencies within vegetable production are limited. Murthy et al..$^{20}$ estimated technical and scale efficiencies for tomato producers in Karnataka, considering different farm sizes (small, medium and large farms), with the use of a data envelopment analysis (DEA). The estimated efficiency levels were $77.7 \%$ for small farms, $82.5 \%$ for medium farms and $72.9 \%$ for large farms. The results showed that an optimal farm size would result in higher technical efficiency levels. They continued to pool the data to estimate the metafrontier (average efficiency score of $86.7 \%$ ), but failed to compare the results for the various sized farms against the metafrontier.

Some of the studies conducted within South Africa include those of Mkhabela ${ }^{21}$ and Khail $e^{22}$. Mkhabela ${ }^{21}$ used a stochastic production function (SFA) approach to investigate vegetable production for small- and large-scale farmers. Mkhabela identified vegetable farmers who produce on an area smaller than 1 ha as small-scale farmers, while those who produce on more than 1 ha as large-scale farmers, and found that large-scale farmers were technically more efficient in vegetable production than were small-scale producers. Khaile ${ }^{22}$ used a DEA approach to estimate technical efficiencies of small- and large-scale raisin producers in Eksteenskuil. Khaile used 
separate optimisations to estimate technical efficiencies for smalland large-scale producers and also found large-scale producers to be more efficient than small-scale producers. The main drawback of the abovementioned studies is that they failed to account for differences in production technology when comparing the production systems. Chen and Song ${ }^{23}$ stated that differences in farming technologies could change the production frontier. Therefore, technical efficiencies from different production frontiers are not comparable. The metafrontier model ${ }^{24}$ makes it possible to calculate comparable technical efficiencies for agricultural farms that operate under different technologies.

The main aim of this study was to compare tomato productivity of commercial and smallholder tomato farmers in the Nkomazi area, Mpumalanga, using a metafrontier analysis. Smallholder and commercial farmers in Nkomazi operate under different production environments, using different technologies to produce tomatoes. Information on commercial and smallholder farmers' production efficiency can help identify strategies to move smallholder farmers into commercial markets.

For this study, smallholder farmers were defined by their limited resource endowment compared to other farmers in the agricultural sector. These farmers were classified as farmers who produced on a very small piece of land, relied mostly on family labour, and produced primarily for home consumption. Commercial farmers produced primarily for a market, had access to productivity-improving resources, and used hired labour.

\section{Data and procedures}

The data for the research were collected from smallholder and commercial tomato farmers in the Nkomazi local municipality located in the Mpumalanga Province of South Africa. Data were collected with the use of a structured questionnaire. Personal interviews were conducted with farmers during May/June 2015 for the 2014/2015 tomato production season. The study was approved by the Ethics Committee of the Faculty of Natural and Agricultural Sciences of the University of the Free State (UFS-HSD2018/0934).

\section{Study area}

The Nkomazi region is known for its dual agriculture system which consists of commercial and smallholder farming. The area has also been described to be among the areas with the highest agricultural potential in South Africa. ${ }^{25}$ The local municipality is situated within the eastern part of the Ehlanzeni District municipality. The Nkomazi region experiences frost-free winters with an average minimum temperature of about $8{ }^{\circ} \mathrm{C}$, which allows production of vegetables and subtropical fruit. ${ }^{26}$ The municipality falls within the summer rainfall region with the rainy season normally lasting from October to March. The estimated mean rainfall for the municipal area varies between approximately $500 \mathrm{~mm}$ and $1600 \mathrm{~mm}$ per annum. ${ }^{27}$ Summers are very hot and humid with an average maximum temperature of about $33^{\circ} \mathrm{C} .{ }^{26}$ The extreme maximum temperature is $41.7^{\circ} \mathrm{C}$ and the extreme minimum $-2.0^{\circ} \mathrm{C}$. The climatic conditions of Nkomazi are suitable for tomato production as tomatoes are a warm season crop that is sensitive to frost. The study area was chosen because of its distinctiveness with regard to agricultural potential. Moreover, the Nkomazi area, known as Malelane, is the main area of tomato production in Mpumalanga.

\section{Sampling procedure and data collection}

A total of 102 tomato farmers were purposively selected and interviewed using a structured questionnaire. The group of sampled farmers consisted of 65 smallholder and 38 commercial farmers. After outliers were removed from the data the sample size was reduced to a total of 87 farmers of which 52 were smallholder farmers and the remaining 35 were commercial farmers. Production data collected with the questionnaire were the amount of tomatoes produced $(\mathrm{kg} / \mathrm{ha})$, fertiliser use $(\mathrm{kg} / \mathrm{ha})$, water use (number of irrigations in a season), seedlings (number of seedlings/ha), labour used (man-days/ha), and the amount of land used for tomato production (ha). The questionnaire also covered socio-economic, institutional and management factors, which were hypothesised to influence technical efficiency of farmers.

\section{Theoretical framework}

\section{Specifying the production frontier}

Others ${ }^{28-30}$ have used both parametric and non-parametric methods to estimate technical efficiency. Both the parametric and non-parametric approaches share a common objective in that a benchmark needs to be identified to test the performance of the rest against that of the best. ${ }^{31}$ The commonly used methods or models for measuring technical efficiency are the stochastic production function and DEA. The former uses econometric methods whereas the latter uses linear programming techniques. ${ }^{28}$ As the stochastic production function and DEA use different methods to fit or determine the frontier, they accommodate differently for random noise and for flexibility in the structure of production technology. 32

Although both techniques have their advantages and disadvantages, DEA was used in the current study because it does not require specification of a production function and therefore avoids model misspecification. ${ }^{33}$ Because the aim of this study was to investigate smallholder and commercial tomato production using current input levels, an outputorientated variable-returns-to-scale model was used to estimate technical efficiency. The output-oriented model allows for the expansion of the amount of tomatoes produced without increasing resource use. The linear programming models for both smallholder and commercial farmers were solved separately using the Benchmarking Package ${ }^{34}$ of $\mathrm{R}^{35}$. The DEA model used to determine farmers' technical efficiency was specified as follows:

$$
\begin{aligned}
& \operatorname{Max}_{\theta i k, \lambda i k} \theta_{i k} \\
& \text { s.t. } \theta_{i k,} y_{i k}-Y_{k} \lambda_{i} \leq 0 \\
& X_{k} \lambda_{i}-x_{i k} \leq 0 \\
& \sum_{i} \lambda_{i}=1 \\
& \lambda_{i} \geq 0
\end{aligned}
$$

Equation 1

where $\theta_{i k}$ is the estimated technical efficiency that shows by how much the output $(y)$ of the ith farm in the group $k$ frontier (smallholder or commercial group) can increase using the same level of inputs $(x) ; y_{i k}$ is a vector $(m \times 1)$ of tomato output produced by the ith farm in group $k ; x_{i k}$ is a vector $(k \times 1)$ of inputs used by the ith farm in group $k ; Y_{k}$ is the tomato output matrix $(n \times m)$ for all $L_{k}$ tomato farms in group $k: X$ is the tomato input matrix $(n \times k)$ for the $L_{k}$ tomato farm in group $k$; and $\lambda$ is a multiplier weight used to weight the input-output decisions of a farmer. The restriction $\sum_{i} \lambda_{i}=1$ allows variable returns to scale. Because Equation 1 estimates output efficiency, the estimated measure of technical efficiency $\left(\theta_{i k}\right)$ ranges from one to infinity. From this score, the technical efficiency of each farmer in each group is estimated as:

$T E^{k}=\frac{1}{\theta_{i k}}$

Equation 2

where $T E^{k}$ defines a technical efficiency score that varies between zero and one. Values of the efficiency score (Equation 2) less than one indicate that output could increase through efficiency gains, without changing the levels of the inputs. The DEA model is estimated $k$ times (once for smallholder and once for commercial tomato farmers), because the smallholder and commercial farmers use heterogeneous technologies. Smallholder and commercial tomato farmers are distinct from one another, because they face different constraints, have different resource endowments, and different opportunities for growth. As a result, the estimated technical efficiencies of heterogeneous groups cannot be compared. The performance of the smallholder and commercial tomato farmers can only be compared when taking the metafrontier as a reference.

\section{Specifying the metafrontier to estimating technical efficiencies}

Comparison of $T E^{\mathrm{k}}$ estimated in Equation 2 could be misleading as the smallholder and commercial farmers do not use the same technology. Therefore, we applied a metafrontier approach to compare technical efficiency of smallholder and commercial farmers. A convex metafrontier 
was fitted using the pooled data ( $L=\Sigma_{k} L_{k}$ farms) to estimate the farmers' technical efficiencies relative to a common benchmark (the metafrontier). The linear programming model for the pooled data solved using the Benchmarking Package ${ }^{34}$ of $\mathrm{R}^{35}$ was specified as:

$$
\begin{gathered}
\operatorname{Max}_{w, \lambda i} \quad W_{i} \\
\text { s.t. } W_{i} b_{i}-B \lambda_{i} \leq 0, \\
A \lambda_{i}-a_{i} \leq 0, \\
\sum_{i} \lambda_{i}=1 \\
\lambda_{i} \geq 0
\end{gathered}
$$

where $W_{i}$ is the technical efficiency estimated for every tomato farmer in the pooled sample; $b$, represents the $M \times 1$ vector of output produced by the ith farm; $a_{i}$ represents the $N \times 1$ vector of inputs used by the $i$ th farm; $B$ represents the $M \times L$ matrix of output produced for all $L$ farms; and $A$ represents the $N \times L$ matrix of inputs used by all $L$ farms. The metafrontier DEA model follows the same mathematical approach as the group frontiers, with only the size of decision-makers $(L)$ changing. Equation 4 was used to estimate the technical efficiencies relative to the metafrontier $\left(T E^{\star}\right)$ :

$$
T E^{*}=\frac{1}{w_{i}}
$$

Equation 4

The metafrontier will never be below the group frontiers; hence, it captures the unrestricted technology set by enveloping the group frontiers. ${ }^{36}$ This implies that even if farmers are technically efficient compared with their own peers in group $k$, they are not necessarily efficient when assessed against the metafrontier.

\section{Specifying the inefficiency model}

James Tobin first introduced the Tobit regression model in $1958 .{ }^{37}$ The Tobit regression is a censored regression model. A censored model implies that the dependent variable is limited by a maximum or minimum value or both. ${ }^{38} \mathrm{~A}$ Tobit model is preferred for cases in which the dependent variable is restricted in some way. ${ }^{39}$ The estimated technical efficiency score is a censored variable with a lower limit of zero (0) and an upper limit of one (1), therefore the Tobit regression model is well suited to estimate the factors affecting farmers' sources of efficiency. The Tobit regression model has also been used in a number of studies ${ }^{25,40-44}$ to determine the factors affecting variation in technical efficiency of farmers.

In the current study, a Tobit model was used to identify sources of variation in technical efficiency for smallholder and commercial tomato farmers. For both regression models, the selected variables were regressed against the technical efficiency scores obtained with Equation 2. The Tobit regression model used to determine the factors that improved the efficiency levels of the smallholder and commercial tomato farmers were specified as:

$$
T E^{k}=\delta_{0}+\sum_{i=1}^{10} \delta_{i} Z_{i}+\varepsilon_{i}
$$

Equation 5

where $T E^{k}$ is the technical efficiency score estimated for farmer $i$ in group $k$ using Equation 2; $\delta_{0}$ is the constant term; $\delta_{i}$ is the vector of unknown parameters to be estimated; $Z_{i}$ represents the variable that may influence the efficiency; and $\varepsilon_{i}$ is the error term. The Tobit models were estimated using Stata. ${ }^{45}$

\section{Empirical application}

\section{Estimating efficiencies}

The group frontiers (smallholder and commercial) and the metafrontier were estimated with the use of the production information obtained with the structured questionnaire. The output variable used in the DEA was tomato output measured in tonne/ha. While the input variables consisted of farmers' fertiliser use (measured in $\mathrm{kg} / \mathrm{ha}$ ), number of seedlings planted on a hectare of land (\#seedlings/ha), and area under tomato production (ha). Farmers were also asked to indicate the volume of water used for irrigation during the production season.
However, because farmers did not know the actual volume of irrigation water applied $(\mathrm{mm})$, they were asked to indicate the number of irrigation sessions during the production season (\#irri/season). Farmers were also asked to indicate the number of labourers employed during the production season. Typically smallholder farmers rely on family labour to produce crops while commercial farmers use hired labour. In this study, both family labour and hired labour were considered for the estimation of the technical efficiencies of tomato farmers. Although the farmers who used family labour did not necessarily pay for labour, there was still an opportunity cost for the family labour (i.e. missed opportunity to increase off-farm income). Furthermore, these farmers still had nonfamily members who assisted with production activities. As few farmers' knew how many hours of labour were spent on tomato production, they were asked to indicate labour use in terms of man-days used to produce tomatoes (man-days/ha). The average, standard deviation, minimum and maximum amounts of tomatoes produced and inputs used by smallholder and commercial tomato farmers are presented in Table 1.

The data showed that smallholder farmers used on average $197 \mathrm{~kg} / \mathrm{ha}$ of fertiliser, 26 irrigation sessions in a season, 8975 seedlings/ha, 755 mandays/ha and 0.3 ha to produce 5 tonnes of tomatoes on a hectare. Commercial farmers used $412 \mathrm{~kg} / \mathrm{ha}$ of fertiliser, 21 irrigation sessions, 20170 seedlings/ha, 336 man-days/ha to produce 96 t/ha on 5 ha of land. Data indicated that commercial farmers used more fertiliser, seedlings and land to produce more tomatoes. More importantly, the commercial farmers used fewer irrigation sessions and less labour to produce more tomatoes compared to the smallholder farmers. The reader is reminded that irrigation is measured as the number of irrigation sessions during a production season and not volume of irrigation water applied. Investigation of the farmers' irrigation practices revealed that smallholder farmers used predominantly watering cans and buckets to water tomato plants and irrigated the plants when the crop or soil appeared dry, whereas the commercial farmers used irrigation technology (e.g. drip irrigation) and a fixed irrigation schedule. The commercial farmers indicated that they irrigated tomato plants every 3-4 days. It is therefore possible that the smallholder farmers applied water every day or every other day, resulting in a higher number of irrigation sessions compared to those of the commercial farmers.

\section{Explaining technical inefficiencies}

The questionnaire included questions on socio-economic, institutional and management factors that were hypothesised to affect the farmers' level of technical efficiency. These variables were regressed against the technical efficiency scores estimated with Equation 2. Because the smallholder and commercial farmers were dealt with separately in the estimation of the efficiencies, two regressions were estimated to explain the sources of inefficiencies. The hypothesised variables, the description of the explanatory variables, and the expected relationship to technical efficiency are given in Table 2.

The socio-economic variables considered in this study included education, experience in tomato production, gender of farm manager (decision-maker), and access to off-farm income. Education and experience were included as continuous variables for which the farmer indicated their age and experience in tomato production in years. Gender of the farm manager was a binary variable, for which 1 indicated male and 0 indicated female. Farmers were asked to indicate if they had access to off-farm income, for which 1 indicated access and 0 no access. The sources of off-farm income were government grants and money sent home by family members who worked in nearby towns or cities.

The farmers were also asked to indicate if they produced tomatoes on rented (coded as a 1) or owned land (0). The expectation was that farmers who used rented land would aim to increase farm profit through better management of resources, in other words that they would aim to maximise technical efficiency. To determine farmers' management practices, farmers were asked to indicate the number of times they applied fertiliser and if they had access to sufficient irrigation water (sufficient water indicated by a 1) to fulfil the crop water requirement. Farmers were also asked to indicate if they used advanced irrigation technologies (1 for drip irrigation) that would increase water use efficiency. 
Table 1: Average, standard deviation (s.d.), minimum (min) and maximum (max) tomato output and inputs used in estimation of technical efficiency

\begin{tabular}{l|l|c|c|c|c|c|c|c|c}
\hline \hline \multicolumn{1}{c|}{ Variable } & \multicolumn{1}{|c|}{ Unit } & \multicolumn{4}{c|}{ Smallholder farmers } & \multicolumn{4}{c}{ Commercial farmers } \\
\hline & & Average & s.d. & Min & Max & Average & s.d. & Min & Max \\
\hline Tomato output $^{\dagger}$ & t/ha & 5 & 5 & 0.33 & 29 & 96 & 17 & 67 & 128 \\
\hline Fertiliser & kg/ha & 197 & 78 & 0 & 340 & 412 & 71 & 250 & 590 \\
\hline Water $^{\dagger}$ & \#irri/season & 26 & 9 & 14 & 44 & 21 & 4 & 12 & 30 \\
\hline Seedlings & \#seedlings/ha & 8975 & 2821 & 5400 & 18000 & 20170 & 3042 & 16000 & 28000 \\
\hline Labour $^{\dagger}$ & man-days/ha & 755 & 300 & 390 & 1560 & 336 & 55 & 233 & 420 \\
\hline Land & ha & 0.3 & 0.2 & 0.1 & 1 & 5 & 1.34 & 3 & 7 \\
\hline
\end{tabular}

tValues were rounded to the closest whole number

Table 2: Description of the production variables and their expected signs

\begin{tabular}{|c|c|c|}
\hline Variable & Description & Expected sign \\
\hline \multicolumn{3}{|l|}{ Socio variables } \\
\hline$Z_{1}=$ education & Years of formal education of farmers & + \\
\hline$Z_{2}=$ experience & Years of experience in tomato production & + \\
\hline$Z_{3}=$ gender & Farmer's gender, 1 if male, 0 if female & + \\
\hline$Z_{4}=$ off-farm income & 1 if farmer received off-farm income, 0 otherwise & + \\
\hline \multicolumn{3}{|l|}{ Institutional variable } \\
\hline$Z_{5}=$ rental land & 1 if farmer rented the farmland, 0 otherwise & + \\
\hline \multicolumn{3}{|l|}{ Management variables } \\
\hline$Z_{6}=$ frequent fertiliser application & Number of fertiliser applications per season & + \\
\hline$Z_{7}=$ access to sufficient irrigation water & 1 if the farmer had access to sufficient irrigation water, 0 otherwise & + \\
\hline$Z_{8}=$ use drip irrigation & 1 if the farmer used drip irrigation method, 0 otherwise & + \\
\hline $\mathrm{Z}_{9}=$ timely planting & 1 if farmer planted at the beginning of the planting season, 0 otherwise & + \\
\hline$Z_{10}=$ staking & 1 if the farmer practised staking, 0 otherwise & + \\
\hline
\end{tabular}

Most smallholder farmers used either buckets or cans and flood irrigation to irrigate tomatoes. The farmers were therefore not certain whether they provided the crop with adequate water, which could have affected the amount of tomatoes produced. The presence of a more advanced irrigation technology was therefore expected to increase technical efficiency.

Farmers were asked to indicate if they were able to plant tomatoes in a timely manner ( 1 indicated ability to plant in a timely manner and 0 not). Lastly, farmers were asked to indicate if they used staking to reduce the occurrence of tomato diseases and pests ( 1 indicated the use of staking, 0 otherwise). It was expected that the use of staking would increase tomato production and thereby increase technical efficiency.

\section{Results and discussion}

\section{Technical efficiency of the group frontiers}

The technical efficiency scores of the smallholder and commercial tomato farmers are presented in Figure 1 as a cumulative density function (CDF). ${ }^{46}$

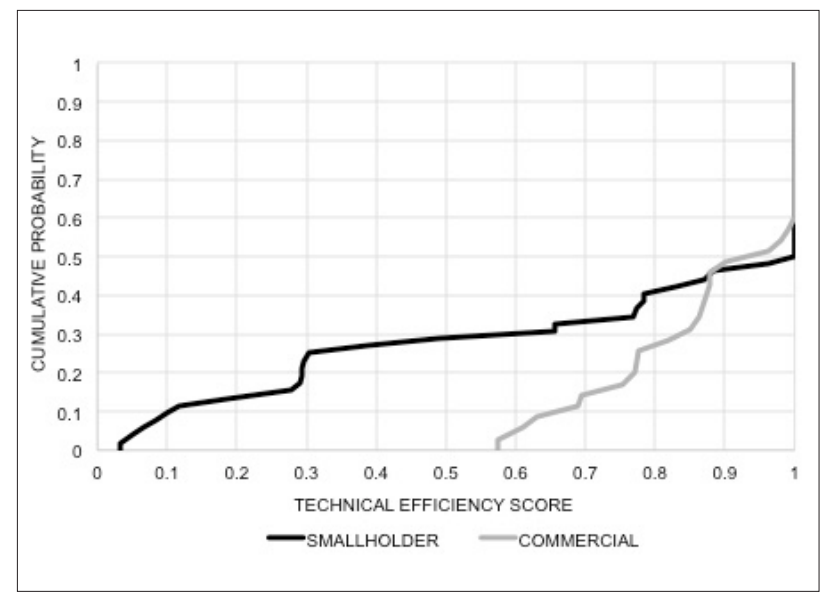

Figure 1: Cumulative probability of smallholder and commercial tomato farmers' technical efficiency scores. 
The CDF indicated the technical efficiency scores as a continuous distribution that could be investigated. The CDF indicated that technical efficiencies of smallholder tomato farmers ranged from $3 \%$ to $100 \%$. The difference between the lowest and the highest efficiency scores indicated that resource use efficiency differed greatly among smallholder tomato farmers. The estimated average technical efficiency score of smallholder tomato farmers was $74 \%$, with a standard deviation of $35 \%$. The average efficiency score revealed that smallholder tomato farmers had the potential to increase tomato output by $26 \%$ (1-0.74) using their current farm resources and technologies. About half $(52 \%)$ of the smallholder farmers operated on the efficiency frontier $(\mathrm{TE}=1)$ while the remaining $48 \%$ operated under the efficiency frontier $(\mathrm{TE}<1)$.

Surprisingly, only $43 \%$ of the commercial farmers operated on the frontier while the majority $(57 \%)$ were not operating on the efficiency frontier. However, the variation in the estimated efficiency scores for the commercial farmers was low, with an average of $89 \%$ and a standard deviation of $13 \%$. In addition, a staggering $95 \%$ of the commercial farmers had a technical efficiency score above $60 \%$, while only $70 \%$ of the smallholder farmers had technical efficiency scores above $60 \%$.

The average technical efficiency scores of smallholder $(74 \%)$ and commercial farmers (89\%) were higher than the respective $69 \%$ and $65 \%$ reported by Enwerem and Ohajianya ${ }^{47}$ for rice farmers in Nigeria. Mburu et al. ${ }^{48}$ in their analysis of economic efficiency of wheat farmers in Kenya found slightly higher technical efficiency scores for smallholder $(85 \%)$ and large-scale $(91 \%)$ farmers. Similarly, Khaile ${ }^{22}$ also found that commercial raisin farmers in Eksteenskuil, South Africa, were more technically efficient $(85 \%)$ than the smallholder raisin farmers $(81 \%)$. About half of the smallholder and commercial tomato farmers in this study were thus technically inefficient based on their estimated group frontiers, meaning that both groups could improve their resource use decisions.

\section{Factors influencing technical efficiency in tomato production}

In order to improve performance, tomato farmers must know what to change or increase in order to increase efficiency. The results for the factors that influenced technical efficiency of smallholder and commercial farmers are presented in Table 3. Results for the smallholder farmers indicated that education, off-farm income, rental land, frequency of fertiliser application, use of drip irrigation and staking of tomatoes had a significant effect on technical efficiency. Increased levels of education resulted in a significant increase $(p<0.05)$ in smallholder tomato production. Results were consistent with those of Itam et al. ${ }^{49}$ and Chepng'etich et al. ${ }^{30}$ who found that smallholder farmers' with a higher level of education were more technically efficient than uneducated farmers. Formal education increased farmers' ability to investigate and adopt new technology, which tended to move farmers closer to the frontier. Similar to the results for commercial farmers, smallholder farmers' efficiency was increased by the availability of off-farm income $(p<0.01)$ and the use of rental land $(p<0.01)$. Again, farmers who had access to off-farm income were better able to obtain improved production inputs and to obtain these inputs in a timely manner. The use of rental land to produce crops indicated that the farmers were not interested in producing for home consumption alone. These farmers would therefore have been interested in increasing the returns they received from renting production land, and therefore it was expected that the renting of agricultural land was associated with more efficient farmers. An increase in the frequency of fertiliser application significantly increased $(p<0.05)$ the efficiency of smallholder tomato production. This result indicates that smallholder farmers who applied fertiliser more often during tomato production were more technically efficient.

Table 3: Factors influencing technical efficiency for smallholder and commercial tomato farmers

\begin{tabular}{|c|c|c|c|c|c|c|}
\hline \multirow{2}{*}{ Variable } & \multicolumn{3}{|c|}{ Smallholder } & \multicolumn{3}{|c|}{ Commercial } \\
\hline & Coefficient & s.e. & Probability & Coefficient & s.e. & Probability \\
\hline \multicolumn{7}{|l|}{ Socio variables } \\
\hline Education & $0.016^{* *}$ & 0.007 & 0.028 & -0.001 & 0.003 & 0.555 \\
\hline Experience & 0.009 & 0.006 & 0.107 & $0.001^{*}$ & 0.000 & 0.060 \\
\hline Gender & 0.047 & 0.047 & 0.271 & $0.030^{*}$ & 0.015 & 0.069 \\
\hline Off-farm income & $0.417^{\star \star \star}$ & 0.076 & 0.000 & $0.072^{\star \star \star}$ & 0.019 & 0.001 \\
\hline \multicolumn{7}{|l|}{ Institutional variable } \\
\hline Rental land & $0.191^{\star * *}$ & 0.058 & 0.002 & $0.039 *$ & 0.020 & 0.062 \\
\hline \multicolumn{7}{|l|}{ Management variables } \\
\hline Frequency of fertiliser application & $0.039 * *$ & 0.016 & 0.019 & $-0.011^{\star \star \star}$ & 0.003 & 0.003 \\
\hline Access to irrigation water & 0.080 & 0.072 & 0.268 & $0.122^{\star \star \star}$ & 0.025 & 0.000 \\
\hline Use drip irrigation & $-0.139 \star \star$ & 0.061 & 0.028 & 0.010 & 0.014 & 0.481 \\
\hline Timely planting & 0.065 & 0.055 & 0.244 & $0.068 * \star$ & 0.025 & 0.012 \\
\hline Staking & $-0.097 \star \star$ & 0.044 & 0.032 & 0.004 & 0.016 & 0.775 \\
\hline Constant & $0.230 \star \star \star$ & 0.065 & 0.001 & $0.745^{\star \star \star}$ & 0.057 & 0.000 \\
\hline /sigma & 0.133 & 0.013 & & 0.034 & 0.004 & \\
\hline Log likelihood & 29.232324 & & & 65.189 & & \\
\hline $\operatorname{LR~chi²}^{2}(10)$ & 100.01 & & & 93.24 & & \\
\hline Prob > chi ${ }^{2}$ & $0.000 * \star \star$ & & & $0.000 * \star \star$ & & \\
\hline Number of observations & 52 & & & 35 & & \\
\hline
\end{tabular}

${ }^{*} 10 \%, * * 5 \%, * * * 1 \%$ 
The use of drip irrigation $(p<0.05)$ and staking $(p<0.05)$ decreased the level of efficiency of tomato production. The results indicated that smallholder farmers who used drip irrigation in the Nkomazi area were technically inefficient. The unexpected negative result was probably because smallholder farmers in the study area lacked the knowledge to use the irrigation technology correctly. Thus the farmers were either under- or over-irrigating the tomatoes. The negative result for staking was not consistent with the results of Gojeh et al. ${ }^{50}$ who found that staking was beneficial in tomato cultivation. During the staking process, plants could have been handled incorrectly (and damaged), thus reducing fruit formation, or the weight of the hanging fruit resulted in injury or stress, thereby reducing the quality and size of the fruit. Alternatively, the use of stacking in combination with the use of inefficient irrigation systems (e.g. watering cans and buckets) could have resulted in waterstressed tomato plants. Staking lifts the plant from the ground, thus exposing the plant and soil to the sun and wind. As a result, plants would have required increased irrigation water as a result of increased evapotranspiration. Failure to supply the required water would result in water stress, decreased plant development, decreased fruit formation, and decreased levels of technical efficiency.

The results in Table 3 indicate that experience, gender, off-farm income, rental land, frequent fertiliser application, access to sufficient irrigation water and timely planting had a significant impact on the technical efficiency of commercial tomato farmers. Experience (0.001) and gender $(0.030)$ were positively related and statistically significant at a $10 \%$ level. The expectation was therefore that male farmers with more experience would be more efficient in commercial tomato production. Over time, farmers are better positioned to obtain new knowledge and skills necessary for choosing new farm technologies that increase technical efficiency. Also tomato production is labour intensive, especially during planting, weeding and harvesting and, therefore, male farmers are expected to be more efficient than their female counterparts. The results are consistent with the results of Mango et al. ${ }^{51}$

As expected, off-farm income (0.072) for commercial farmers was positively related and statistically significant at a $1 \%$ level. It was expected that farmers who had a source of off-farm income were more technically efficient than commercial farmers with no off-farm income. Off-farm income increased the chance for farmers to easily and timeously buy important inputs such as fertiliser and pesticides. Results also indicated that the use of rental land to produce tomatoes $(p<0.1)$ increased the farmers' technical efficiency. These results were similar to that of Chimai ${ }^{29}$ who found that using rented land had a positive influence on efficiency in field crop production because renting land is an added cost to the farmer. The farmer would therefore wish to be more efficient in their production, in order to justify the additional costs of renting land.

It was expected that frequent application of fertiliser would increase farmers' technical efficiency. However, results indicate that frequent fertiliser application reduced commercial farmers' technical efficiency at a statistically significant $1 \%$ level. There are a number of possible explanations for the negative relationship to fertiliser application. One possible explanation could be that the farmers over-utilised fertiliser trying to improve output, while the over-utilisation of fertiliser probably resulted in a decrease in tomato output. Another possible explanation could be that the fertiliser was applied at the wrong times. However, it is difficult to tell exactly what the cause of the negative coefficient was, as we did not test for over-application of fertiliser or the timing of fertiliser application.

Access to sufficient irrigation water $(p<0.01)$ and the timely planting of seedlings $(p<0.05)$ increased technical efficiency for commercial tomato production. Results indicated that access to enough water for irrigation in tomato production was important and hence increased technical efficiency. The planting of tomatoes early in the production season (timely planting of tomatoes) would have increased technical efficiency. Commercial farmers indicated that the challenge with late tomato planting in Nkomazi was the weather. During planting, rain could have resulted in blight fungal disease, because the leaves remained wet for extended periods.

\section{Tomato farmers' technical efficiency relative to the metafrontier}

The results for the group frontiers indicated that the technical efficiency levels for the smallholder and commercial farmers were different. However, the group frontiers cannot be used to draw a conclusion regarding the similarity or differences in the farmers' resource use management decisions, as the farmers faced different environmental and production conditions. As a result, a metafrontier was estimated to present a common frontier that could be used for comparison of the farmers with the common benchmark. A comparison between the distribution of technical efficiency scores for the group frontiers and relative to the metafrontier is indicated in Figure 2 as a CDF. SMALLHOLDER and COMMERCIAL are used to denote the technical efficiency of the smallholder and commercial tomato farmers, respectively. An asterisk $\left({ }^{*}\right)$ is used to indicate the technical efficiency relative to the metafrontier.

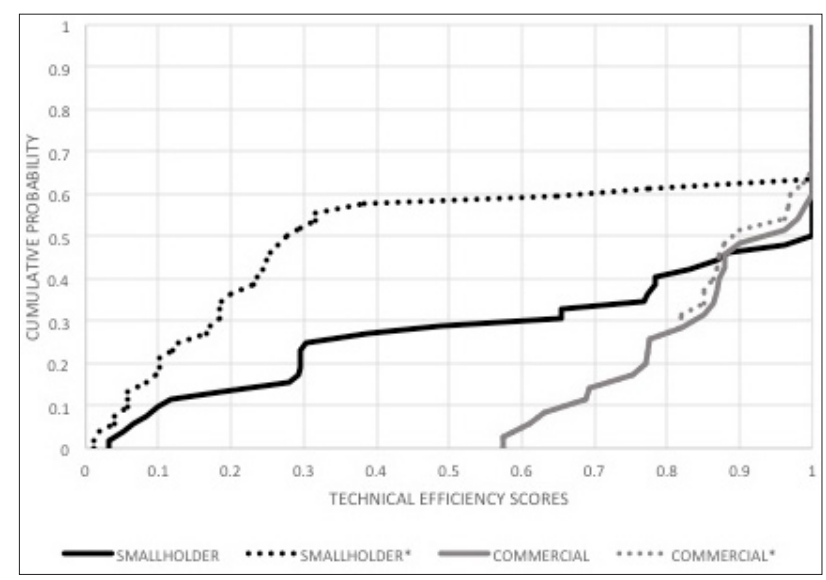

Figure 2: Cumulative probability for the group frontiers (solid lines) and technical efficiency relative to the metafrontier (broken lines).

The CDF indicates that smallholder farmers' technical efficiency relative to the metafrontier $\left(\mathrm{TE}^{\star}\right)$ ranged from $1 \%$ to $100 \%$. The wide range in estimated technical efficiency scores of smallholder farmers indicates the huge variation in resource use efficiency. It is interesting to note that about $38 \%$ (1-0.62) of the smallholder farmers were technically efficient $(100 \%)$ relative to the metafrontier, while nearly $50 \%$ of the farmers were efficient relative to the group frontier. A large group of the farmers $(58 \%)$ had an efficiency score (TE*) below $40 \%$; as a result the smallholder farmers' average efficiency level relative to the metafrontier was $51 \%$ compared to the $74 \%$ for the group frontier. Results for the technical efficiency of smallholder farmers indicate that the level of inefficiency estimated relative to the metafrontier was higher than that estimated for the smallholder group frontier. The implication of this result is that the average smallholder farmers found it difficult to compete with the farmers who formed the common benchmark.

The average $\mathrm{TE}^{\star}$ score estimated for the commercial farmers was $88 \%$ with a standard deviation of $13 \%$. The variation in the estimated $\mathrm{TE}^{*}$ for commercial farmers was much lower than that estimated for the smallholder farmers. Even though some farmers showed a slight decrease in their estimated TE* compared with the TE estimated from the group frontier, the average TE* decreased by $1 \%$ to $88 \%$. The number of farmers who were producing on the frontier decreased from $43 \%$ for the group frontier to $37 \%$ for the metafrontier. Therefore, the results indicate that, compared to the common benchmark, the commercial farmers were performing much better than the smallholder farmers, with more commercial farmers operating closer to the common benchmark. This result is similar to that of Temoso et al..$^{52}$ who found that commercial beef producers' average technical efficiency relative to the metafrontier (74\%) was higher than that of traditional farms (smallholder farmers) (71\%) in Botswana. 


\section{Conclusion}

Our aim was to investigate the technical efficiencies of smallholder and commercial tomato farmers in the Nkomazi area of South Africa. Identification of the differences in these farmers' technical efficiencies and the factors that influence their level of inefficiency can help identify strategies to move smallholder farmers into commercial markets.

Results for the group technical efficiencies showed that smallholder and commercial tomato farmers were fairly efficient with an average efficiency of $74 \%$ and $89 \%$, respectively. There was, however, still some room for improvement, which was highlighted by the large variability in smallholder technical efficiency. In conclusion, both groups of farmers were fairly efficient when compared to their peers. However, some of the commercial and smallholder farmers could still improve their technical efficiency by improving their input use decisions.

The results from the Tobit model show that experience, gender, off-farm income, rental land, frequent fertiliser application, access to sufficient irrigation water and timely planting had a significant impact on technical efficiency of commercial tomato farmers in Nkomazi. Education, off-farm income, rental land, frequent fertiliser application, use of drip irrigation and staking of tomatoes were significant factors for technical efficiency in smallholder tomato production. Results for the factors influencing farmers' technical efficiency indicate that the factors which increased or decreased technical efficiency were different for smallholder and commercial farmers. Only two factors had a significantly positive effect for both groups of farmers: off-farm income and the renting of additional land. The remaining variables indicated that management decisions (frequency of fertiliser applications, use of irrigation and irrigation technology, timely planting and staking) impacted smallholder and commercial farmers' technical efficiency in tomato production. The conclusion is that assistance provided to tomato farmers should focus on production management.

The results for the metafrontier again show that the commercial farmers were fairly efficient in tomato production, with an average efficiency of $88 \%$. The smallholder tomato farmers were much less efficient compared to the metafrontier, with an average efficiency of $51 \%$, although there were some smallholder farmers with scores on the metafrontier. The results therefore indicate that the smallholder tomato farmers would have to make fairly substantial changes to their production practices, which include their production technologies, in order to compete with the farmers who represented the metafrontier. However, it would not make sense for the smallholder farmers to improve their production relative to the metafrontier if they were still under-performing compared with their peers, as measured with the group frontier. Therefore, smallholder farmers must first increase their technical efficiency relative to other smallholder farmers, before aiming to improve relative to the metafrontier and, in so doing, commercial farmers.

A possible means to provide assistance to farmers could be through extension services. However, the extension officers should be trained to provide guidance to farmers regarding appropriate management decisions which would improve farmers' technical efficiency. Farmers should be encouraged to utilise existing agricultural support programmes like Masibuyele emasimini ('going back to till the land') that aim to improve farmers' productivity. These support programmes should be tailored to provide production management guidance and not only provide inputs to beneficiaries. However, more empirical research is needed to fully understand the technical efficiency differences between smallholder and commercial farmers. A better understanding of such differences will allow for the development of better systems to assist both smallholder and commercial farmers, and could provide the necessary understanding on how to integrate smallholder farmers into commercial markets.

\section{Acknowledgement}

This work was supported by the Agricultural Research Council (ARC) under the Professional Development Program (PDP). Financial and other assistance by the ARC are gratefully acknowledged.

\section{Authors' contributions}

J.Z.G.: data collection, data analysis, writing the initial draft, funding acquisition. N.M.: student supervision, writing revisions, critically reviewing the writing

\section{References}

1. Greyling JC. The role of the agricultural sector in the South African economy [master's dissertation]. Stellenbosch: Stellenbosch University; 2012.

2. Sandrey R, Vink N. Trade and innovation project case study 4: Deregulation, trade reform and innovation in the South African agriculture sector. OECD Trade Policy Working Papers No.76. Paris: OECD; 2008. http://dx.doi. org/10.1787/240428414841

3. Tshuma MC. Understanding the small-scale agricultural sector as precondition for promoting rural development in South Africa. Afr J Agric Res. 2014;9(31):2409-2418. https://doi.org/10.5897/ajar12.1631

4. South African Department of Agriculture. The strategic plan for South African agriculture. Pretoria: Directorate Agricultural Information Services; 2001.

5. South African Department of Agriculture, Forestry and Fisheries. Strategic plan for smallholder support 2011-2014/15. Pretoria: Directorate of Small Holder Development; 2013.

6. Pienaar CJ. Increased water productivity in irrigated tomato production in the smallholder farming community of Giyani [master's dissertation]. Stellenbosch: Stellenbosch University; 2014.

7. Nkamleu GB, Nyemeck J, Diakalia S. Metafrontier analysis of technology gap and productivity differences in African agriculture. J Agri Food Econ. 2006;1(2):111-120.

8. Obwona M. Determinants of technical efficiency differentials amongst small and medium scale farmers in Uganda: A case of tobacco growers. AERC Research paper 152. Kenya: African Economic Research Consortium; 2006

9. Najjuma E. Technical efficiency of tomato production: A comparative study between small scale green house and open field tomato farmers in Kiambu. J Agr Policy. 2017;1(1):16-36.

10. Shrestha RB, Huang WC, Pradhan U. Evaluating the technical efficiency of smallholder vegetable farms in diverse agroecological regions of Nepal. Int J Food Agric Econ. 2016;4(4):97-112.

11. Belete A, Setumo MP, Laurie SM, Senyolo MP. A stochastic frontier approach to technical efficiency and marketing of orange fleshed sweet potato (ofsp) at farm level: A case study of KwaZulu-Natal Province, South Africa. J Hum Ecol. 2016;53(3):257-265.

12. Malinga NG, Masuku MB, Raufu MO. Comparative analysis of technical efficiencies of smallholder vegetable farmers with and without credit access in Swaziland: The case of the Hhohho Region. Int $J$ Sustain Agric Res. 2015;2(4):133-145. https://doi.org/10.18488/ journal.70/2015.2.4/70.4.133.145

13. Etim NA, Udoh EJ. Identifying sources of efficiency among resource poor indigenous vegetable farmers in Uyo, Nigeria. Int J Food Agric Econ. 2014;2(1):33.

14. Donkoh SA, Tachega M, Amowine N. Estimating technical efficiency of tomato production in Northern Ghana. Am J Exp Agr. 2013;3(1):56-75. https://doi. org/10.9734/AJEA/2013/1447

15. Khan REA, Ghafar $\mathrm{S}$. Technical efficiency of tomato production: A case study of District Peshawar (Pakistan). World App Sci J. 2013;28:1389-1392.

16. Ogunniyi LT, Oladejo JA. Technical efficiency of tomato production in Oyo State Nigeria. Agr Sci Res J. 2011;1(4):84-91.

17. Abdulai A. Resource use efficiency in vegetable production: The case of smallholder farmers in Kumasi metropolis [master's dissertation]. Kumasi: Kwame Nkrumah University of Science and Technology; 2006.

18. Karunarathna M. Estimating technical efficiency of vegetable farmers in Anuradhapura District in Sri Lanka. J Econ Res. 2014;2(2):55-67.

19. Sartorius Von Bach HJ, Townsend RF, Van Zyl J. Technical inefficiency of commercial maize producers In South Africa: A stochastic frontier production function approach. Agrekon. 1998;37(2):162-170. https://doi.org/10.1080/ 03031853.1998.9523502 
20. Murthy DS, Sudha M, Hegde MR, Dakshinamoorthy V. Technical efficiency and its determinants in tomato production in Karnataka, India: Data envelopment analysis (DEA) approach. Agr Econ Res Rev. 2009;22(2):215-224.

21. Mkhabela T. Technical efficiency in a vegetable based mixed-cropping sector in Tugela Ferry, Msinga District, KwaZulu-Natal. Agrekon. 2005;44(2):187204. https://doi.org/10.1080/03031853.2005.9523709

22. Khaile PME. Factors affecting technical efficiency of small-scale raisin producers in Eksteenskuil [master's dissertation]. Bloemfontein: University of the Free State; 2012.

23. Chen Z, Song S. Efficiency and technology gap in China's agriculture: A regional metafrontier analysis. China Econ Rev. 2008;19(2):287-296. https:// doi.org/10.1016/j.chieco.2007.03.001

24. Battese GE, Rao DSP, O'Donnell C. A metafrontier production function for estimation of technical efficiencies and technology gaps for firms operating under different technologies. J Productiv Anal. 2004;21:91-103. https://doi. org/10.1023/b:prod.0000012454.06094.29

25. Thabethe LS. Estimation of technical, economic and allocative efficiencies in sugarcane production in South Africa: A case study of Mpumalanga growers [master's dissertation]. Pretoria: University of Pretoria; 2013.

26. Van Niekerk G. Farms on Mpumalanga achieving high return on investment [webpage on the Internet]. c2015 [cited 2016 Jun 10]. Available from: http:// www.pamgolding.co.za/property-news/2015/3/13/farms-in-mpumalangaachieving-high-return-on-investment

27. South African Department of Agriculture and Land Administration. Strategic plan 2007/2008-2009-2010. Nelspruit: Mpumalanga Provincial Government; 2007.

28. Tipi T, Yildiz N, Nargeleçekenler M, Çetin B. Measuring the technical efficiency and determinants of efficiency of rice (Oryza sativa) farms in Marmara region, Turkey. N Z J Crop Hortic Sci. 2009;37(2):121-129. https://doi. org/10.1080/01140670909510257

29. Chimai BC. Determinants of technical efficiency in smallholder sorghum farming in Zambia [master's dissertation]. Columbus, $\mathrm{OH}$ : Ohio State University; 2011.

30. Chepng'etich E, Nyamwaro SO, Bett EK Kizito K. Factors that influence technical efficiency of sorghum production: A case of small holder sorghum producers in lower Eastern Kenya. Advances Agr. 2015;2015, Art. \#861919, 11 pages. http://dx.doi.org/10.1155/2015/861919

31. Fried HO, Lovell CK, Schmidt SS. Efficiency and productivity. The measurement of productive efficiency and productivity growth. New York: Oxford University Press; 2008. https://doi.org/10.1093/acprof:0so/9780195183528.001.0001

32. Porcelli F. Measurement of technical efficiency. A brief survey on parametric and non-parametric techniques. Coventry: University of Warwick; 2009. Available from: http://www.warwick.ac.uk/fac/soc/economics/staff/phd students/porcelli/porcelli_dea_sfm.pdf

33. Sarafides V. An assessment of comparative efficiency measurement techniques. Occasional Paper 2. London: Europe Economics; 2002.

34. Bogetoft $P, 0$ tto L. Package benchmarking. Benchmark and frontier analysis using DEA and SFA [webpage on the Internet]. c2015 [cited 2015 Sep 16]. Available from: https://cran.r-project.org/

35. R Core Team. A language and environment for statistical computing. Vienna: R Foundation for Statistical Computing; 2013. Available from: http://www.Rproject.org/
36. O'Donnell CJ, Rao DP, Battese GE. Metafrontier frameworks for the study of firm-level efficiencies and technology ratio. Empirical Econ. 2008;34(2):231255. https://doi.org/10.1007/s00181-007-0119-4

37. Tobin J. Estimation of relationships for limited dependent variables. Econometrica. 1958;26(1):24-36. https://doi.org/10.2307/1907382

38. Carson RT, Sun Y. The Tobit model with a non-zero threshold. Econometrics J. 2007;10:488-502. https://doi.org/10.1111/j.1368-423x.2007.00218.x

39. Bhatt MS, Bhat SA. Technical efficiency and farm size productivity-micro level evidence from Jammu and Kashmir. Int J Food Agric Econ. 2014;2(4):27-49.

40. Awotide DO, Kehinde AL, Akorede TO. Metafrontier analysis of access to credit and technical efficiency among smallholder cocoa farmers in Southwest Nigeria. Int Bus Res. 2015;8(1):132-144. https://doi.org/10.5539/ibr. v8n1p132

41. Sibiko KW, Owuor G, Birachi E, Gido EO, Ayuya OI, Mwangi JK. Analysis of determinants of productivity and technical efficiency among smallholder common bean farmers in eastern Uganda. Current Res $\mathrm{J}$ Econ Theory. 2013;5(3):44-55.

42. Bougna E, Crozet $Y$. Estimating technical and allocative efficiency using stochastic cost frontier: an application to railway. Paper presented at: The European Transport Conference 2013: Big Data; 2013 September 30 October 2; Frankfurt, Germany.

43. Otieno DJ, Ruto E, Hubbard L. Determinants of technical efficiency in beef cattle production in Kenya. Paper presented at: The International Association of Agricultural Economists (IAAE) Triennial Conference; 2012 August 18-24; Foz do Iguacu, Brazil.

44. Chavas JP, Petrie R, Roth M. Farm household production efficiency: Evidence from the Gambia. Am J Agr Econ. 2005;87(1):160-179. https://doi. org/10.1111/j.0002-9092.2005.00709.x

45. StataCorp. Stata statistical software release 14. College Station, TX: StataCorp LP; 2015.

46. Hardaker JB, Lien G, Anderson JR, Huirne RB. Coping with risk in agriculture: Applied decision analysis. Oxfordshire: CABI Publishing; 2015. https://doi. org/10.1079/9781780645742.0000

47. Enwerem VA, Ohajianya DO. Farm size and technical efficiency of rice farmers in Imo State, Nigeria. Greener J Agri Sci. 2013;3(2):128-136.

48. Mburu S, Ackello-Ogutu C, Mulwa R. Analysis of economic efficiency and farm size: A case study of wheat farmers in Nakuru District, Kenya. Econ Res Int. 2014:1-10. http://dx.doi.org/10.1155/2014/802706

49. Itam KO, Ajah EA, Ofem UI, Abam OE. Technical efficiency analysis of small scale cassava farmers in Cross River State, Nigeria: A stochastic production frontier approach. Appl Econ Finan. 2015;2(4):10-18. https://doi. org/10.11114/aef.v2i4.1028

50. Gojeh AJ, Belew D, Mohammed A. Yield and quantity of indeterminant tomato (Lycopetsicon esculentum Mill.) varieties with staking in Jimma. Singapore J Sci Res. 2012;2(2):33-46. https://doi.org/10.3923/sjsres.2012.33.46

51. Mango N, Makate C, Hanyani-Mlambo B, Siziba S, Lundy M. A stochastic frontier analysis of technical efficiency in small-scale maize production in Zimbabwe: The post-fast-track land reform outlook. Cogent Econ Finance. 2015;3, 1117189, 14 pages. https://doi.org/10.1080/23322039.2015.111 7189

52. Temoso 0, Villano R, Hadley D. Evaluating the productivity gap between commercial and traditional beef production systems in Botswana. Agric Syst. 2016;149:30-39. https://doi.org/10.1016/j.agsy.2016.07.014 